\title{
POSTER KECANDUAN GAME TERHADAP ANAK USIA DINI
}

\author{
Fanny Azka Fadillah ${ }^{1}$, Muhammad lqbal' \\ Program Studi Desain Komunikasi Visual \\ Fakultas Bahasa dan Seni, Universitas Indraprasta PGRI \\ Jl. Nangka 58 Tanjung Barat, Jakarta Selatan, 12530
}

\begin{abstract}
Abstrak. Tujuan perancangan poster dampak bermain game terhadap anak usia dini adalah sebagai media penyuluhan untuk orang tua agar memperhatikan dan membimbing anak dalam bermain game. Hal ini dilatar belakangi oleh adanya fenomena anak yang kecanduan bermain game, yang ditandai dengan adanya dorongan untuk melakukan secara terus menerus yang disertai penarikan diri, ketidak mampuan mengatur waktu, mempunyai masalah dengan pengaruh interpersonal dan kesehatan. Akan tetapi, game tidak hanya memiliki dampak negatif, tetapi juga terdapat dampak positif jika anak bermain game jika dimainkan dalam porsi yang pas. Tulisan berdasar studi pustaka ini menguraikan dampak yang terjadi pada anak jika bermain game, baik dari sisi negatif maupun sisi positif. Selain itu tulisan ini juga menguraikan panduan orang tua untuk membimbing anaknya ketika bermain game. Karena Dalam tumbuh kembang anak pasti mengalami masa eksplorasi, namun masa ini juga membutuhkan pengawasan dari orang tua. Pengawasan itu bertujuan untuk mengarahkan anak agar memperoleh manfaat dari eksplorasi secara tepat.
\end{abstract}

Kata Kunci: Dampak, game, anak, kecanduan, poster.

\begin{abstract}
The purpose of designing posters on the impact of playing games on early childhood is as an extension media for parents to pay attention to and guide children in playing games. This is motivated by the phenomenon of children who are addicted to playing games, which is characterized by the urge to do it continuously which is accompanied by withdrawal, inability to manage time, problems with interpersonal and health influences. However, the game not only has a negative impact, but also has a positive impact if the child plays the game if played in the right portion. Writing based on this literature study describes the impact that occurs on children when playing games, both from the negative side and the positive side. In addition, this paper also outlines parental guidelines for guiding their children when playing games. Because in child development, they certainly experience a period of exploration, but this period also requires supervision from parents. The supervision aims to direct children to benefit from exploration appropriately.
\end{abstract}

Keywords: Impact, game, child, addiction, poster.

Correspondence author: Fanny Azka Fadillah, fannyazka98@gmail.com, Jakarta, Indonesia

This work is licensed under a CC-BY-NC 


\section{Pendahuluan}

Perkembangan teknologi di era globalisasi ini mengalami perkembangan yang pesat, hal ini secara tidak langsung memberikan pengaruh besar bagi kehidupan manusia dalam berbagai aspek. Teknologi yang menjadi kebutuhan dasar manusia didukung dengan perkembangan ilmu pengetahuan yang pesat. Perkembangan teknologi berkembang secara drastis dan terus berevolusi hingga sekarang dan semakin mendunia. Hal ini dapat dibuktikan dengan banyaknya inovasi dan penemuan yang sederhana hingga sangat rumit.

Game merupakan suatu kegiatan menghibur diri sendiri dan menghilangkan rasa penat setelah melakukan aktivitas sehari-hari. Biasanya game dimainkan ketika waktu senggang sehingga tidak mengganggu aktivitas sehari-hari. Kegiatan ini biasanya membutuhkan peralatan berupa papan permainan, komputer game, konsol, dan lain-lain.

Game (permainan) merupakan salah satu dari hasil perkembangan teknologi. Permainan yang awalnya dimainkan di dunia nyata dengan berinteraksi dengan orang atau benda secara langsung, kini bisa dimainkan dalam bentuk digital menggunakan teknologi. Teknologi game sudah meluas ke berbagai sektor kehidupan. Saat ini game dapat diperoleh dengan mudah melalui aplikasi dan media internet. Berbagai teknologi game akan mengalami pertumbuhan fenomenal di masa mendatang. Berbagai game dengan teknologi yang lebih canggih akan bermunculan.

Saat ini sudah jarang anak-anak yang bermain permainan tradisional. Mereka beralih pada permainan digital yang dirasa lebih praktis. Pilihan anak ini juga karena dukungan dari orang tua, yang menyediakan berbagai fasilitas untuk bermain game supaya anak tidak rewel. Game tidak hanya memiliki dampak negatif saja, namun juga memiliki dampak positif bagi anak, salah satunya yakni dapat meningkatkan sistem motorik bagi anak dan dapat meningkatkan bahasa asing bagi anak, karena pada saat ini kebanyakan game menggunakan bahasa Inggris.

Pembatasan bermain game ini berhak dilakukan oleh orang tua demi perkembangan pribadi anak. Peran orang tua sebagai pelindung, pengawasm dan panutan bagi anak sangatlah penting. Hal ini dikarenakan orang tua merupakan sosok yang paling dekat dengan anak dan merupakan sosok utama yang bertugas sebagai pembimbing bagi perkembangan anak. Karena suatu saat anak akan tumbuh berkembang dan menjadi bagian masyarakat. Mereka akan bermanfaat bagi banyak orang, serta menjadi bagian dari pribadi yang membangun bangsa.

Perancangan poster ini bertujuan untuk menghasilkan sebuah poster dengan desain dan bahasa yang tepat untuk target khalayak. Poster harus mampu menyampaikan informasi atau pesan pada audiens yang sedang sibuk, hanya dalam hitungan detik. Karena waktu baca yang begitu singkat dan dalam situasi sibuk. Oleh karena itu, harus ditentukan pesan apa yang akan dijadikan elemen kunci yang akan disampaikan melalui poster tersebut.

Dalam pembuatannya, poster harus sesuai dengan pesan yang disampaikan, singkat, padat, menarik, dan mudah dimengerti oleh pembaca. Tujuan dari poster ini nantinya akan membentuk sikap atau pandangan pada orang tua terhadap anaknya dalam bermain game bahwa orang tua tidak perlu melarang anak untuk bermain game namun orang tua harus berperan mengawasi dan membatasi anak dalam bermain game. 


\section{Metode Penelitian}

Penelitian ini merupakan penelitian studi literatur dengan menelaah literatur berupa jurnal, skripsi, dan buku tentang game. Hasil dari telaah literatur ini akan digunakan untuk memberikan solusi desain bagi permasalahan dampak game bagi anak usia dini.

\section{Hasil dan Pembahasan}

\section{Bermain}

Secara Bahasa, bermain diartikan sebagai suatu aktivitas yang langsung atau spontan, dimana seorang anak berinteraksi dengan orang lain, benda-benda di sekitarnya, dilakukan dengan senang (gembira), atas inisiatif sendiri, menggunakan daya khayal (imajinatif), menggunakan panca indra, dan seluruh anggota tubuhnya.

Menurut Brooks, J. B. dan D. M. Elliot (dalam Latif et al. 77), "bermain" (play) merupakan istilah yang digunakan secara bebas sehingga arti utamanya mungkin hilang. Arti yang lebih tepat ialah setiap kegiatan yang dilakukan untuk kesenangan yang ditimbulkannya, dan tanpa mempertimbangkan hasil akhir. Bermain dilakukan secara sukarela dan tidak ada paksaan atau tekanan dari luar atau kewajiban.

Dari pernyataan di atas dapat disimpulkan bahwa bermain merupakan suatu kegiatan seorang anak yang sudah melekat dalam dirinya untuk berinteraksi dengan orang lain atau benda-benda di sekitarnya. Dalam bermain anak menggunakan daya khayalnya untuk membangun tingkat kreativitas pada dirinya sehingga dapat menimbulkan pada anak itu.

\section{Game}

Kemajuan teknologi yang semakin pesat ternyata juga memengaruhi aktivitas bermain anak. Sekarang, anak-anak lebih sering bermain permainan digital seperti video game,Playstation (PS), dan games online (Nur)

Game berasal dari Bahasa Inggris yang berarti dasar permainan. Permainan merupakan bagian dari bermain dan bermain juga bagian dari permainan, keduanya saling berhubungan. Permainan adalah kegiatan yang kompleks, di dalamnya terdapat peraturan, play dan budaya. Permainan adalah sebuah sistem dimana pemain terlibat dalam konflik buatan. Peraturan dalam permainan bertujuan untuk membatasi perilaku pemain dan menentukan permainan. Pada dasarnya permainan merujuk pada pengertian kelincahan intelektual (Intellectual Playability Game) yang juga bisa diartikan sebagai arena keputusan dan aksi pemainnya. Dalam game ada target-target yang ingin dicapai pemainnya (Istiqomah 13).

Game atau permainan merupakan bentuk kegiatan untuk menghibur diri sendiri serta menghilangkan rasa penat dalam melakukan aktivitas keseharian. Seiring perkembangan zaman, game atau permainan pun juga ikut mengalami perubahan. Kemajuan teknologi dan informasi membuat berbagai macam permainan terus berkembang. Salah satu permainan yang banyak diminati yaitu game online. Game online adalah sebuah permainan yang hanya dapat dioperasikan menggunakan koneksi internet (Kurniawan 98).

Berdasarkan pendapat di atas dapat disimpulkan bahwa game adalah suatu kegiatan yang kompleks dan terdapat sistem dimana pemain terlibat dalam konflik buatan. Bermain game merupakan bentuk kegiatan untuk menghibur diri senidiri dan menghilangkan rasa apenat dalam melakukan aktivitas keseharian, sehingga jika dilihat dari tujuan utamanya bermain game seharusnya tidak dapat mengganggu aktivitas keseharian manusia. 


\section{Dampak positif dan negatif bermain game}

Saat ini anak-anak bisa dengan mudah memilih game yang ingin dimainkan tanpa mengetahui jenis game apa dan batasan usia yang diberikan untuk bermain game tersebut. Sehingga game tersebut akan memberikan dampak pada mereka.

\section{Dampak negatif}

1. Kecanduan dan ketergantungan

Bermain game dengan frekuensi dan intensitas yang besar dapat memberikan efek samping kecanduan dan ketergantungan. Adapun akibat yang dimunculkan individu akan ditantang terus-menerus untuk menekuninya.

Bila memainkan game yang membutuhkan konsentrasi, maka dampak psikologis yang dirasakan adalah akan merasa penasaran sehingga mengabaikan apa saja demi memenangkan permainan itu. Kalau hal ini terjadi anak-anak, biasanya mereka menjadi malas untuk melakukan aktivitas lain seperti mandi, makan, bahkan belajar demi sebuah kemenangan game.

\section{Mengganggu kesehatan}

Akibat secara tidak langsung dalam jangka Panjang yakni masalah kesehatan. Daya tahan tubuh menjadi lemah karena frekuensi berlebihan di layar terpaku sambil memainkan joystick bahkan melupakan jam makan. Menurut jurnal kesehatan di Inggris diberitakan bahwa seseorang mengalami "sindrom vibrasi" pada jari jemarinya. Hal ini diakibatkan si anak menghabiskan waktu rata-rata tujuh jam setiap hari dengan memanfaatkan controller getar. Berarti adanya indikasi bahwa game dapat mengganggu kesehatan individu adalah nyata.

3. Perilaku menyimpang

Perilaku menyimpang timbul karena adanya ketidakpuasan terhadap sebuah harapan. Pada dasarnya setiap aksi membutuhkan tindakan dari si pemain untuk mencapai kemenangan, yang sering kali pula diperlukan alasan tertentu sebagai reaksinya. Ada asap tentunya karena ada api. Jika seorang anak yang sangat maniak bermain game dengan intensitas tertentu dapat menimbulkan dampak psikologis sebuah ilusi yakni tidak dapat membedakan mana perilaku yang benar atau sesuai dengan norma di kehidupan nyata. Sebab tebayang akan perilaku tokoh dalam game.

Para peneiti telah memberikan pendapat bahwa dalam bermain game membutuhkan pengulangan dalam mencapai tujuan agar bisa menang serta mendapat nilai tertentu. Kemudian, game juga akan membentuk pola piker terhadap pemainnya sehingga akibatnya membentuk perilaku menyimpang, baik itu disadari maupun tidak disadari. Dari sisi konten, game yang bergenre kekerasan dan perang menampilkan adegan pembunuhan, penembakan, dan perkelahian.

4. Isolasi sosial

Lain pula dengan masalah ini, anak begitu betahnya ketika sudah bermain game. Sehingga orang lain tidak bisa mengganggunya dan juga menutup diri terhadap apa yang terjadi di sekitarnya. Adapun efek yang ditimbulkan dapat mengganggu kejiwaannya dan dalam hubungan dengan teman sebayanya dan orang sekitarnya pun merasa terganggu. Karena game yang dimainkan sangat bersifat individual, hanya dapat dilakukan sendiri tanpa melibatkan orang lain. Biasanya jenis game yang dimainkan secara online dengan internet. 
Dari hal ini game yang tidak offline dengan internet, sangat memberikan pengaruh terhadap pergaulan antara pemain game dan orang sekitarnya terutama jika dapat dimainkan oleh dua pemain atau lebih.

5. Intimidasi gender

Adapun karakter dalam permainan game kadang bersifat antagonis, sehingga menunjukkan kekerasan dan melontarkan kata-kata kasar. Namun bisa juga muncul penggabungan dua karakter seperti dalam game Tomb Raider dengan bentuk kompetisi, peperangan, serta petualangan. Di dalam game Tomb Raider itu pula, tokoh wanitanya digambarkan sebagai orang yang ahli dalam bela diri dan sering kali berkata kasar. Adanya karakter seperti ini dapat memberikan contoh yang buruk bagi anak-anak terutama identifikasinya terhadap seoran wanita.

6. Kekerasan

Karena seringnya individu memainkan game yang bertemakan kekerasan maka akan berpengaruh terhadap pandangan kekerasan di kehidupan nyata. Lambat laun akan mengikis pandangan norma sehingga memotivasi untuk melakukan tindakan kekerasan di kehidupan nyata.

\section{Dampak positif}

1. Membuat orang pintar

Dr. Jo Bryce dari Machester University telah membuktikan game membuat orang menjadi pintar. Di dalam penelitian tersebut, bahwa pemain game yang bermain game 18 jam per minggu akan memiliki koordinasi yang baik antara tangan dan mata, bila dibandingkan setara dengan kemampuan atlet. la juga menambahkan bahwa gamer memiliki daya konsentrasi tinggi sehingga mampu menuntaskan beberapa tugas.

2. Meningkatkan ketajaman mata

Para peneliti yang berasal dari Rochester University mengungkapkan bahwa anakanak yang memainkan game bergenre kekerasan secara teratur memiliki ketajaman mata yang lebih cepat daripada mereka yang tidak terbiasa dengan joypad.

Perkembangan yang lain ikut terpengaruh adalah perkembangan motoric dan perkembangan kognitif. Anak yang bermain game dengan tangkas akan merangsang sistem motorik berkembang sesuai dengan gerakan yang dilibatkan. Di dalam perkembangan kognitif, anak akan mengatasi perubahan dari waktu satu ke waktu yang lainnya.

3. Rajin membaca

Ada pernyataan bahwa video game diciptakan bukan untuk menggantikan buku. Namun pernyataan tersebut disangkal oleh seorang psikolog yang berasal dari Finland University. Beliau mengatakn bahwa konten dari video game sangat membantu anak-anak dyslexia untuk meningkatkan kemampuan membaca.

Adapun game yang dimaksud adalah game bergenre Role Playing Game (RPG), yang berisi dialog-dialog seperti yang terdapat pada game Final Fantasy dan game Phantasy Star. Adapun manfaat yang lain adalah mampu memacu otak anak untuk mencerna cerita serta memberikan pengaruh terhadap perkembangan bahasa. Karena anak menjadi terbiasa mendengar, membaca kosa kata, dan mengucapkan kata baik bahasa asing dan bahasa lokal. 
4. Mengenal teknologi baru dari sebuah game

Pemain game yang getol pasti mengetahui bahwa konten dari game disesuaikan dengan keadaan sekarang. Pada dasarnya, game konten baru muncul ketika sedang terjadi teren tertentu. Sebut saja ketika piala dunia, maka game dengan konten sepak bola segera muncul di pasaran dengan memuat kesebelasan yang berasal dari peserta piala dunia. Bukan suatu rekayasa dengan tampilan yang realistis.

5. Meningkatkan kecepatan dalam mengetik

PC game yang dikendalikan keyboard computer juga membawa dampak positif bagi pemainnya terutama meningkatkan kecepatan dalam mengetik. Apalagi jika memainkan game online di mana pemain dapat berkomunikasi dengan pemain lain dengan mengetik kata atau kalimat. Maka anda akan dituntut mengetik secara cepat sekaligus mengendalikan game. Dengan dampak itu maka logika dalam berpikir juga mengalami perkembangan.

6. Relaksasi

Para peneliti di Indiana University membuktikan bahwa bermain game dapat mengendurkan ketegangan urat saraf. Ketegangan akan mengendor apabila game digunakan sebagai tempat pelampiasan. Pelampiasan dalam membuang segala kejengkelan yang menimpa individu (Tridhonanto 28-37).

\section{Panduan untuk orang tua}

Dalam tumbuh kembang anak pasti mengalami masa eksplorasi namun masa ini juga membutuhkan pengawasan dari orang tua. Pengawasan itu bertujuan untuk mengarahkan anak agar memperoleh manfaat dari eksplorasi secara tepat. Ketika anak memainkan game ia juuga telah melakukan eksplorasi. Maka dari itu sebaiknya sebagai orang tua memperhatikan gamegame yang sedang dimainkan anaknya. Bila perlu terlibat dalam aktivitas anak, karen hal itu menolong anda dan mengerti apa saja yang mereka butuhkan. Berikut adalah panduan orang tua untuk mendampingi anak dalam bermain game.

1. Membatasi lama bermain game

Bermain game sebaiknya dibatasi bukan setiap saat memainkan game dengan durasi yang cukup lama. Paling tidak dalam sehari hanya satu jam memainkan game.

2. Memanfaatkan sumber informasi yang resmi apabila bermain game secara online dan situs yang mengulas game

Biasanya beberapa keterangan game akan dicantumkan dalam situs tersebut termasuk juga cara bermainnya. Namun yang paling penting perhatikan rating ESRB, apakah sesuai dengan umur anak. Beberapa perusahaan pengembang game memasang rating ESRB pada tiap produknya. Pastikan anak memainkan game sesuai dengan kebutuhan dan perkembangan jiwanya.

3. Meletakkan player game atau komputer di dalam ruang keluarga

Tempatkanlah player game atau komputer di dalam ruang keluarga hal ini agar lebih mudah dalam mengawasi game yang dimainkan anak. Selain itu juga melatih rasa berbagi dengan anggota keluar lain yakni dapat memainkan game itu secara bersama-sama saat waktu senggang. 
4. Memperhatikan gejala kecanduan bermain game

Bila melihat anak mulai mengalami gejala kecanduan game maka hentikan penggunaan game. Tentu saja penghentian ini sebaiknya tidak dilakukan tiba-tiba karena justru anak merasa gusar dan bisa saja ia akan berusaha memainkan game di tempat lain tanpa diketahui orang tua.

5. Sesekali bermain Bersama anak dalam bermain game

Game dapat dijadikan hiburan keluarga sebab game dapat dimanfaatkan secara Bersama-sama. Bermain Bersama anak akan menjadi hal yang menyenangkan sekaligus dapat mengawasinya secara langsung. Sebab orang tua di era digital memang harus mengerti benar game yang sesuai dngan usia anak..

6. Membicarakan isi game yang mereka mainkan

Game dapat membantu dalam menambah wawasan ilmu pengetahuan. Salah satunya game yang bergenre kuis seperti Who Wants to Be Millionare yang mencampurkan merode belajar dengan metode bermain.

Diskusi mengenai mengenai isi game dengan anak dapat menggali perasaan yang dirasakan anak ketika bermain, apakah suka atau tidak? Dialog seperti ini dapat membangun hubungan harmonis dengan anak.

7. Anjurkan anak bermain dengan teman secara offline

Game sebenarnya bukan satu-satunya hiburan karena masih banyak kegiatan permainan yang dapat dilakukan sebagai hiburan. Permainan-permainan yang dapat dilakukan Bersama teman di dunia nyata masihlah banyak. Misalnya melakukan kegiatan olahraga seperti bermain sepak bola, kasti, ataupun basket. Atau permainan tradisional seperti kucing-kucingan, lompat tali, atau gobak sodor. Dengan demikian anak mengalami keseimbangan antara dunia nyata dan fantasi dalam game.

8. Sebaiknya hindari genre game First Peson Shooter yang mengangkat adegan pembunuhan

Di pasaran banyak game FPS atau First Peson Shooter yang mengangkat adegan pembunuhan. Game sejenis ini dikemas cukup menarik sehingga anak-anak dan remaja berminat untuk memainkannya. Namun adegan pembunuhan sadis digambarkan dengan cukup nyata misalnya memotong kepala orang hingga darahnya bercucuran (Tridhonanto $\underline{45-50})$.

\section{Hasil dan Pembahasan}

Poster

Media adalah sesuatu yang digunakan untuk merangsang pikiran, perasaan, perhatian, minat peserta didik sedemikian rupa sehingga proses belajar terjadi, salah satu media yang dapat dimanfaatkan untuk meningkatkan kognitif peserta didik adalah media visualisasi. Media yang tepat dalam menerima informasi yang baik adalah media poster. Poster adalah kombinasi visual dari rangcangan yang kuat, dengan warna, dan pesan dengan maksud untuk menangkap perhatian. Poster juga disebut plakat, lukisan atau gambar yang dipasang sebagai media untuk menyampaikan informasi, saran, pesan, kesan, ide yang berfungsi untuk menarik perhatian, memperjelas sajian ide, mengilustrasikan atau menghiasi fakta yang mungkin cepat akan 
dilupakan. Poster merupakan alat pembelajaran untuk menambah kosa kata (Rizawayani et al. 128).

Poster dapat berfumgsi untuk menarik minat peserta didik terhadap pesan-pesan yang ingin disampaikan, mencari dukungan tentang sesuatu hal/gagasan, serta sebagai metode peserta didik untuk tertarik dan melaksanakan pesan yang terpampang dalam poster serta memungkinkan untuk dilihat sesering mungkin tanpa harus menyala komputer dan televisi (Shalwa et al. 2).

Hasil dari pembahasan "Dampak Bermain Game Terhadap Anak Usia Dini" adalah sebuah poster yang berisikan ajakan kepada orang tua untuk membimbing anak dalam bermain game dan bermain game bersama anak. Karena bermain game dengan anak dapat membangun hubungan antara anak dan keluarga, dan juga dapat melatih kerja sama anak dan orang tua. Selain itu kini video game sudah dimainkan oleh banyak anak anak, sehingga apabila anak dilarang nantinya anak akan terlihat gagap teknologi oleh temannya dan tidak bisa berinteraksi terhadap temannya. Alasan kenapa lebih memilih untuk mengajak orang tua bermain dengan anak daripada melarangnya karena pada game tersebut tidak hanya memiliki dampak negatif saja, melainkan juga memiliki dampak positif bagi anak.

\section{Analisis Khalayak}

Segmentasi

Segmentasi dari poster ini adalah Orang Tua karena ingin memberikan contoh bagaimana untuk bijak dalam mengawasi anaknya dalam bermain game dengan cara bermain game Bersama dengan anaknya. Berikut merupakan rincian segmentasi poster :

1. Geografis

Perancangan poster ini akan dihadirkan dan dibaca oleh orang tua yang memiliki anak dikota-kota besar seperti Kota Jakarta serta kota-kota lain yang ingin nengajak untuk mengawasi dan bermain bersama anaknya melalui illustrasi poster.

2. Demografis

a. Usia

Segmentasi demografis yang dituju pada media poster ini pada adalah orang tua yang memiliki anak dengan rentang usia 10-15 tahun. Dimana dalam rentang usia tersebut anak-anak akan harus diawasi dalam bermain game.

b. Jenis Kelamin

Poster ini dapat dibaca atau dilihat oleh laki-laki maupun perempuan.

3. Psikografis

Psikografis masyarakat yang menjadi sasaran dalam perancangan poster ini adalah orang tua yang sibuk dalam bekerja sehingga dengan adanya poster ini mampu mangajak orang tua agar lebih sering mengosongkan waktunya untuk buah hati mereka. 


\section{Proses Perancangan Poster}

1. Membuat illustrasi seorang ayah

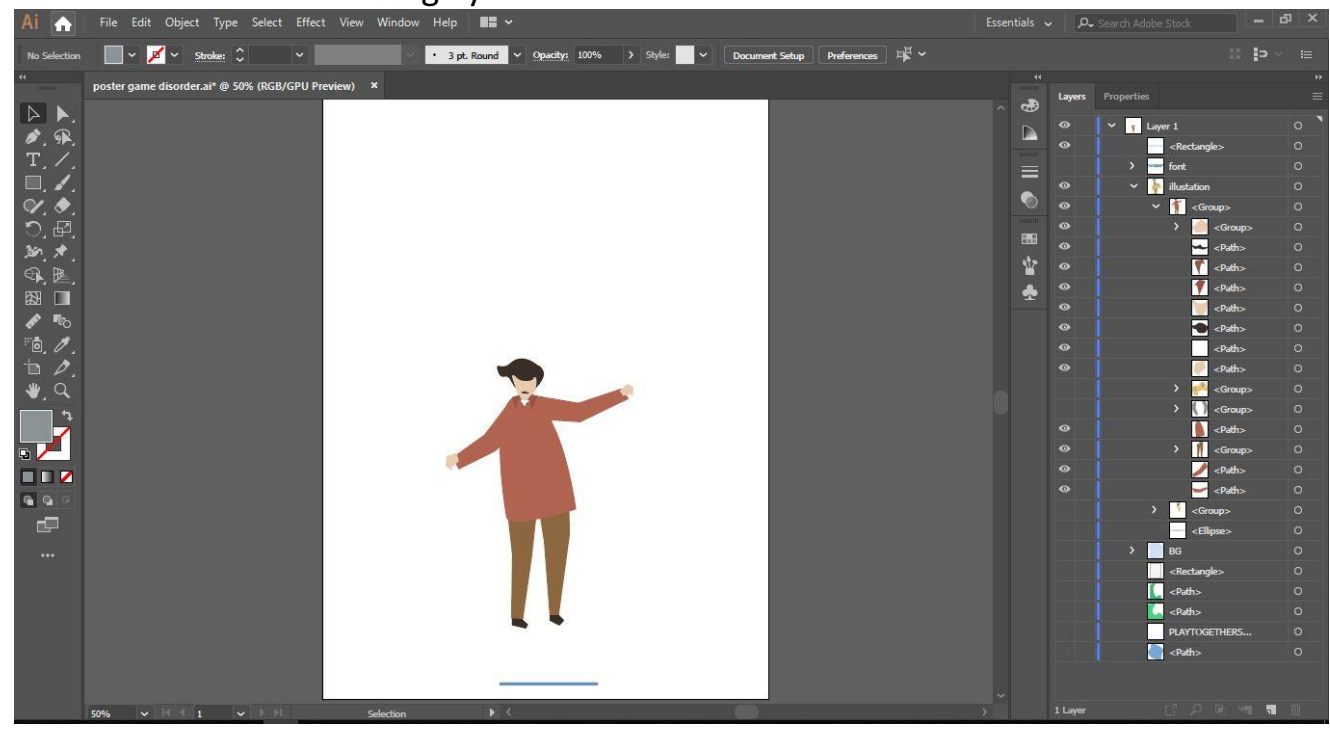

Gambar 1 Illustrasi Ayah

Sumber: Dokumentasi Pribadi

Pada gambar pertama dibuat illustrasi seorang ayah untuk poster ini.

2. Membuat illustrasi seorang anak

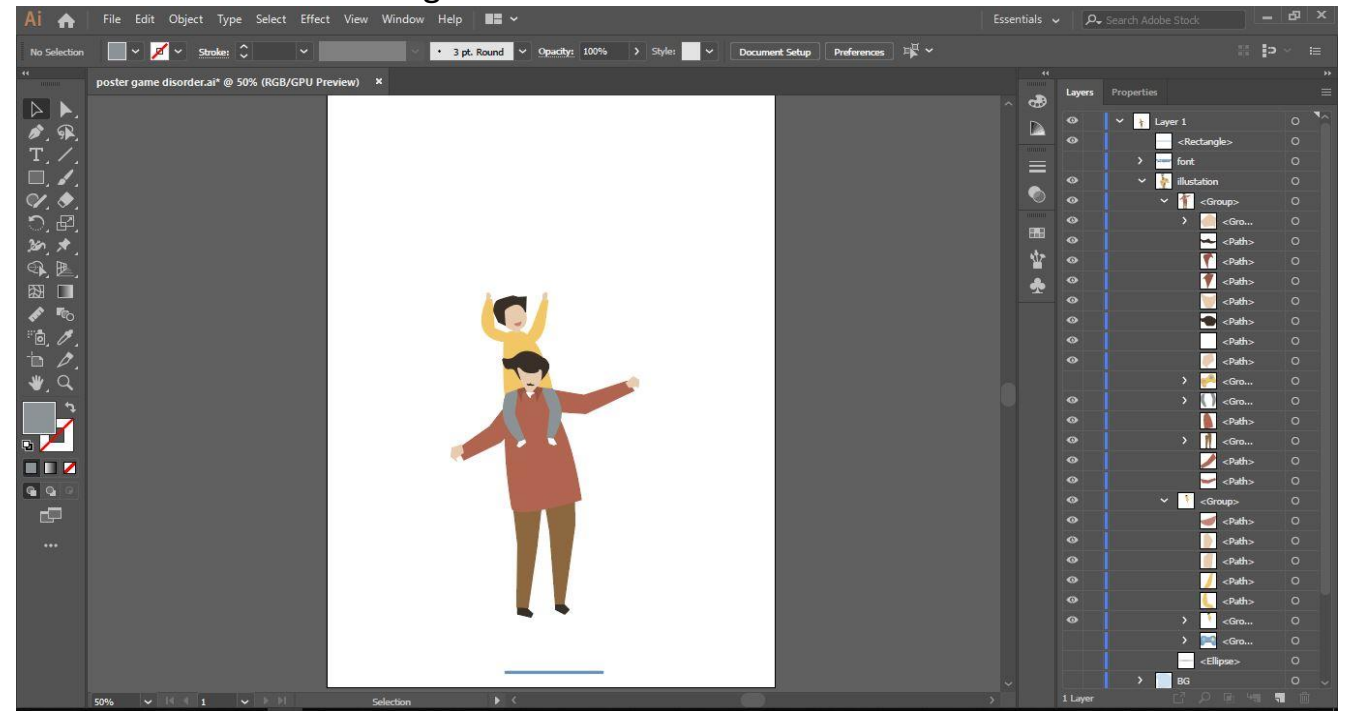

Gambar 2 Illustrasi Anak

Sumber: Dokumentasi Pribadi

Pada gambar kedua dibuat illusttrasi seorang anak yang sedang bermain Bersama ayahnya. 
3. Membuat illustrasi Joystick dan menambahkan tipografi untuk Key Message poster.

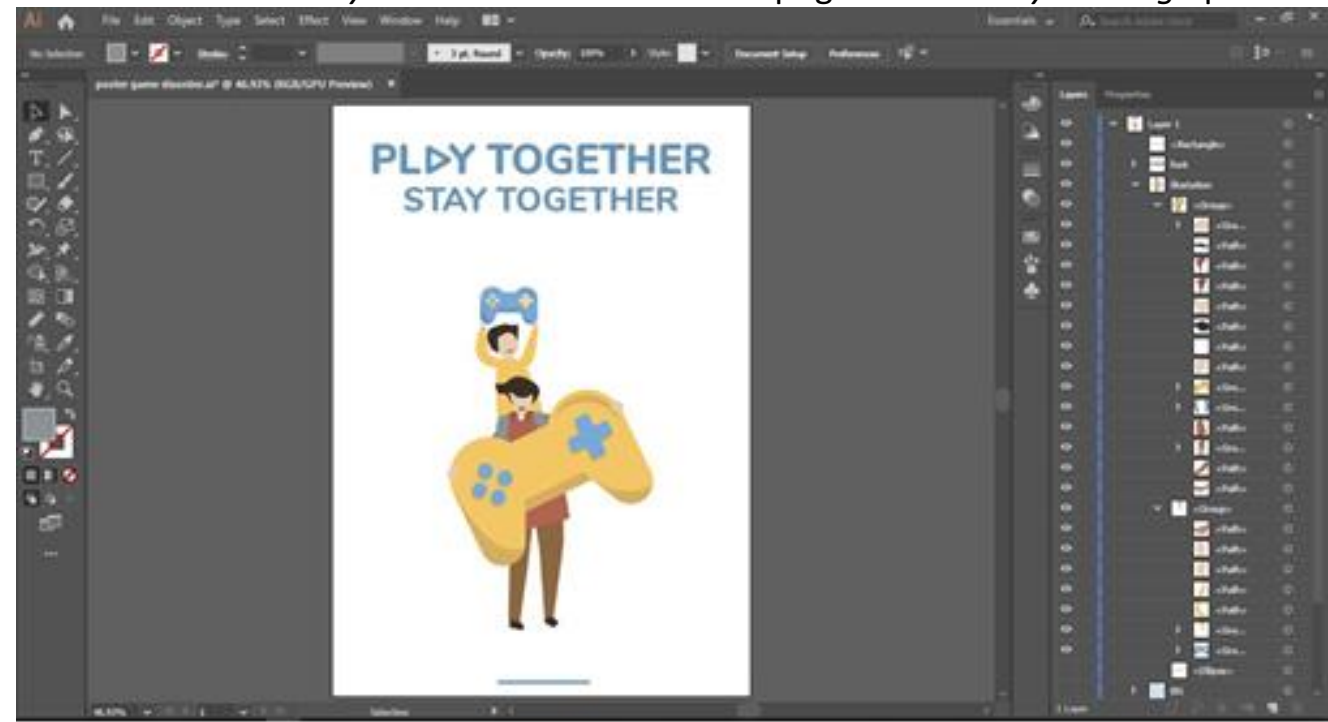

Gambar 3 Illustrasi Poster beserta tipografi Sumber: Dokumentasi Pribadi

Pada gambar ketiga ini dibuat illustrasi Joystic sebagai elemen pendukung pada poster yang dimaksudkan untuk memperjelas bahwa poster tersebut bertemakan game. Dan terdapat Key Message bertuliskan "Play Together Stay Together. "Makna dari key message tersebut adalah jika orang tua dan anak bermain game bersama nantinya akan muncul kebersamaan dalam keluarga, karena anak sudah menganggap orang tuanya seperti teman mainnya, dan akan tercipta juga kerja sama keluarga dalam memecahkan masalah karena bermain bersama.

\section{Hasil Perancangan Poster}

Setelah sudah selesai dengan tahapan proses sketsa poster, berikut merupakan hasil perancangan poster.

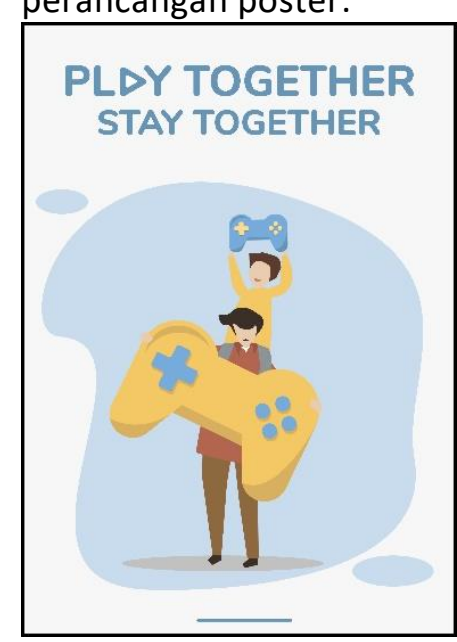

Gambar 4 Poster

Sumber: Dokumentasi Pribadi

Desain poster ini diharapkan dapat disukai dan menjadi solusi permasalahan bagi para pembacanya yang sebagian besar merupakan orang tua yang ingin menjaga anaknya dari 
kecanduan bermain game. Poster ini juga merupakan ajakan dan memiliki pesan utama yaitu pentingnya bermain Bersama antara anak dan orangtua. Warna yang dipilih pada desain poster ini adalah warna-warna yang menarik dan nyaman untuk dilihat.

\section{Simpulan}

Dengan dibuat poster ini kami berharap orang tua dapat lebih memperhatikan dan mengawasi buah hatinya agar terhindar dari kecanduan bermain game yang dapat merusak kesehatan mentalnya. Bermain game bersama selain sebuah solusi untuk menghindari kecanduan bermain game pada anak juga bisa untuk mempererat hubungan antara anak dan orangtua.

\section{Daftar Pustaka}

Istiqomah, Kholifah. "Dampak Game Pada Kepribadian Sosial Anak (Studi Kasus Kelas V Sd Islam Al-Madina Semarang)." vol. Undergraduate (S1), Skripsi, UIN Walisongo, 2016. http://eprints.walisongo.ac.id/6197/http://eprints.walisongo.ac.id/6197/.

Kurniawan, Drajat Edy. "Pengaruh Intensitas Bermain Game Online Terhadap Perilaku Prokrastinasi Akademik Pada Mahasiswa Bimbingan Dan Konseling Universitas Pgri Yogyakarta." Jurnal Konseling GUSJIGANG, vol. 3, no. 1, 2017, pp. 97-103, https://jurnal.umk.ac.id/index.php/gusiigang/article/view/1120.

Latif, Mukhtar et al. Orientasi Baru Pendidikan Anak Usia Dini Teori \& Aplikasi. Kencana Prenadamedia Group, 2013.

Nur, Haerani. "Membangun Karakter Anak Melalui Permainan Anak Tradisional." Jurnal Pendidikan Karakter, no. 1, 2013, pp. 87-94, https://journal.uny.ac.id/index.php/ipka/article/view/1290.

Rizawayani, Rizawayani et al. "Pengembangan Media Poster Pada Materi Struktur Atom Di Sma Negeri 12 Banda Aceh." Jurnal Pendidikan Sains Indonesia, vol. 5, no. 1, 2017, pp. 127133, http://www.jurnal.unsyiah.ac.id/JPSI/article/view/8435.

Shalwa et al. "Pembuatan Poster Keanekaragaman Fitoplankton Di Danau Biru Singkawang Pada Sub Materi Keanekaragaman Hayati Di Sma." Jurnal Pendidikan dan Pembelajaran, vol. 4, no. 5, 2015, http://jurnal.untan.ac.id/index.php/ipdpb/article/view/10162.

Tridhonanto, Al. Optimalkan Potensi Anak Dengan Game. PT. Elex Media Komputindo, 2011. 